\title{
Institutional Political Developments from the Assembly of Durres to the Congress of Lushnja
}

\author{
Eldi Sherifi \\ PhD candidate, Faculty of Law, University of Tirana
}

Doi:10.5901/ajis.2016.v5n2p187

\begin{abstract}
There are several historical studies on the Congress of Durrës and Congress of Lushnja, but in my opinion further studies should be conducted on the history of political institutions and their political organizing operators as well as their inhibitors. On July 29, 1913 the Great powers declared Albania a Hereditary and Sovereign Autonomous Principality. At the Peace Conference in 1919, Clemenceau and Lloyd defended the thesis of "inability of Albanians to Self Government" and offered the solution of sharing the governance responsibility between Yugoslavia and Italy to implement the Secret Treaty of London on 26 April 1915. The Congress of Durres was held after the conclusion of the First World War. It was led by Mehmet Konica and Myfit Libohova. Delegates elected the interim government and the delegation for representing Albania at the Peace Conference in Paris. The Congress of Lushnja came as an illuminating meteor in the dark and hopeless institutional environment. Its development destroyed the anti-Albanian political intrigues. After they toppled the government of Durres by voting against it, the congress delegates established all the powers of the state, according to the principles of Montesquieu. Through several transparent procedures they established "National Council", "Supreme Council" and the Cabinet. The evidence and acts sources of law served as the legal basis. Influenced by Sami Frashëri they intertwined the historical tradition with the modern political philosophy of constitutional law of Kelzen. The Congress, after re-established the institutions, de jure abolished the international acts that violated the sovereignty and the state became Western-oriented.
\end{abstract}

Keywords: National Assembly, National Council, Supreme Council, Senate, Cabinet.

\section{Introduction}

World War I brought new political realities for Albanians, after the dualistic Austro-Hungarian Empire was "dissolved, in the same way that the Ottoman Empire was "dissolved" after the Balkan War. From this moment, the political rivalry between Italy and Austria "stopped" for the domination of Albania. The political influence of Turkey and Bulgaria in Albania has been weakened because they were part of the loser coalition of the war. This geopolitical imbalance favored Italy's political influence, which after World War I, with the support of Britain and especially France, absolutely controlled the territories of Albania.

A group of Albanians in Geneva urged Italy to remove the Serbs and Greeks from Albania and guaranteed the rights of Albanians, according to the proclamation Ferrero and the declaration of Baron Sonnino in the Chamber of Deputies. The participants of the political debate were: Myfit Libohova, Mehdi Frashëri, Turhan Pasha, Mustafa Kruja, Vlora Syrja do, Mehmet Bey Këlcyra, Mit'hat Frasheri and Pandeli Cale (Marenglen Verli, Tirana: Neriada, 2000, p. 150). The event must be true because it was stated by one of the participants of the meeting, Syrja Vlora, who was in contact with the Italian authorities (Syrja Vlora, memories, Tirana: Iceberg, 2012, p. 168).

The Congress of Durres was prepared in these circumstances. The historical facts "overthrow" the opinion of any scholar, as if the Italians were caught by surprise when the delegates approved the establishment of the National Council of Durres (A. Puto, political Albania ...., p. 222).

Aiming to learn even about the institutional historical realities of the Congress of Lushnja, let's refer to the publication made by the Directorate of State Archives, on the occasion of the 15th anniversary of the liberation of Albania, 1959, entitled "Documents and historical material from the war the Albanian people for freedom and democracy 19171941". ${ }^{1}$ The documents also contain archival data for the Congress of Lushnja. The opening of the first national meeting 
took place on 21-01-1920, by delegates arrived at the meeting room in the house of Mr. Kaso Fuga ${ }^{2}$. Publishers have removed some sentences like "after a prayer of the honorable Sheh Ibrahim Karbunara, Mr. Ferid Vokopola, held a lecture on behalf of the Commission of Lushnja" and "Mr. Aqif Pashë Elbasani replied to the speech of Ferid Vokopola using ardent patriotic words"! Mr. Ferid Vokopola has been temporarily appointed Chairman of the Assembly and a special commission has been elected to examine the letters of representation of the delegates, consisting of five persons as follows: Ibrahim Bey Ohri, Qasim Kokoshi, Kostaq Kota, Fasli Frashëri and Adem Peqini. After the election of the Commission for verifying the mandates it was decided that the meeting shall cease the actiivity until of the majority of delegates arrive". 3

The same is repeated in the second opening of the congress on 28-01-1920, where about 4 lines of the text were missing. The following sentences have been removed: Xhavit Leskoviku, on behalf of the initiating group, explained the reason why the Congress was held. At the same time, the election of the chairman of the Congress, Mr. Aqif Pasha, as wll as the vice chairman Kota Kostaq and the secretaries Sotir Peci and Ferid Vokopola has been removed. ${ }^{4}$ In the record was written that in honor of the deceased Abdul Ypi, which was assasined due to the attemption to stop the National Meeting, it was decided that the assembly should be stopped in these days and a letter of condolence from the meeting should be sent to the family of the deceased. ${ }^{5}$

Such facts clearly show that the names of the real institutional protagonists have been "erased" from our political history and the events and dates gained significant importantance. Therefore, a false perception is created as our political history is extremely poor and its protagonists are counted on the fingers of one hand, leaving the main protagonists in "historical oblivion".

\section{Metodology}

In my doctoral dissertation I used the method of historical narrative description combined with the principle of historical criticism. Historical variables have been used for the verification of the hypothesis. The unused data of State Archives, foreign literature and publications and monographs of the authors participating in the event have been the reference source. The historical facts were accepted as historical truth after being confronted with with variables addressed by local and foreign authors.

\section{Institutional historical journey from the Assembly of Durres to the Congress of Lushnja}

The historical moment should not break away from the Assembly of Durres in order to argue that the Congress of Lushnja was a historical necessity. The main organizer of the Assembly of Durres was Mehmet Konica. For his development he displayed diplomatic, political and organizational skills and thus he deserves the affirmation of unknown values. He moved around Albania, and was able to gather in Durres 59 representative delegates. The delegates were elected by the prefectures and municipalities, according to the experience gained for the Assembly of Vlora. Among the delegates there were former ministers, diplomatic representatives in different countries, prefects, mayors, senior officials of the state administration as well as representatives of the clergy in Albania. The Congress of Durres was held on December 25, 1918, at 16.00 p.m., under the direction of co-chairmen Mehmet Konica and Mufid Libohova. The minutes held for this event says that delegates from all parts of Albania formed a national meeting. ${ }^{6}$ It was attended by delegates from Delvina: Namik Bey Delvina and Hiqmet Bey Delvina; from Gjirokastra: Myfit Bey Libohova, Polo Meksi, Petro Poga, Apostol Dhima, atty.Vasil Dilo and Anastas Noti; from Tepelena: Sulejman Shehu and Koço Harito; from Përmet: Baba Xhemali and Dhimitër Kacimbra; from Kolonja: Abdulla Beu and Petër Prodani; from Dëshnica of Këlcyra: Baba Mustafai and Baba Hyseni; from Frashëri: Behxhet Selfua; from Kurveleshi: Ali Koka; from Berati: Sami Bey Vrioni, Dhimitër Tutulani and Fejzi Bey Alizoti; from Fier: Qemal Bey Vrioni and Leon Xoxa; from Mallakastra: Hajredin Bey Cakrani and Kamber Belishova; from Lushnja: Ahmed Bey Resuli and Jakov Bozua; from Skrapar: Xhelal Bey Koprencka and Servet Bey Zaloshnja; from Elbasani: Shefqet Bey Vërlaci, Lef Nosi and Ahmed Dakli; from Peqini, Ismail Haki Kadiu and M.

2lbid p. 21

${ }^{3}$ AQSH, p. 55, d.62, p. 3, Circulars of the Ministry of the Interior in 1920, Shkodër; Nika, 1921, p. 3.

${ }^{4}$ Historical documents and materials from the Albanian people's struggle for freedom and independence, 1917-1941, edition of AQSH Tirana, 1959, p. 22

5lbid p. 22

${ }^{6}$ AQSH. P. 249.D.I-1842. f. 1-2. poses 4. 
Xhavid Metobashi; from Kavaja: Qazim Bey Hyti and Sheih Hamidi; from Tirana: Abdi Bey Toptani, Ismail Efendi Ndrogi and Shefki Kondi; from Kruja: Muharrem Pengili and Xhemal Belegu; from Shijak: Ymer Bey Shijaku and Rexhep Jella; from Mat: Abdurrahman Bej Çela and Hasan Bej Zagolli; from Shkodra: Riza Dani and Ndoc Çoba; from Durrës: Hafiz Ali, (may have been named Hafiz Ali Korça E.sh) Mihal Truja and Mustafa. Shkodra was represented by Luigj Gurakuqi. The assembly has not been attended by Abdi Bey Toptani, Ndoc Çoba, Sotir Peci and Starje Pojani. Idhomen Kosturi participated in the second session. The congressional hearings have not been attended by the delegates of Vlora: Qazim Koculi, Spiro Koleka, Qazim Kokoshi, Ymer Radhima and Myqerem Hamzaraj, who were in Durres, but were not allowed to enter the assembly by the Italian representatives who surveyed its development. The meeting was not attended by Aqif Pasha as well, "not because he was old and frightened by the bad weather and the bed roads", which he burst with the heart of politician two years later; when he was even older he was elected Chairman of the Congress of Lushnja and the Supreme Council. His letter is a historical document proving that the personalities of the time were invited as delegates at the Assembly of Durres, accompanied with documents "identified pursuant to the law", a fact which legitimizes and certifies his political activity and the institutions that he established. In his letter Aqif Pashë Elbasani, called Mehmet Konica "Honest Chairman of the Albanian Meeting" (Marenglen Verli, p. 300-301). Aqif Pasha's letter has institutional historical value because it reflects his high legal and political culture when he demanded that his letter be read in "The Expanded Congress", the one that "his heart said that it would do great works". And according to him, Albania's status was acquired by the decision of the Great Kingdom of the London Conference, and that decision neither was demolished nor was outdated, therefore ordered the Assembly to preserve "the form of government established by the Conference of London" (Marenglen Verli, Ferit Duka: Mother Teresa, 2007, p. 300-301).

The main organizer of the Assembly of Durres was Mehmet Konica who was commissioned by the director of "Albanian Office" in Rome according to the order of the Minister Sonnino that delegates should have a mandate for the establishment of the "Executor Committee" and not of a government (Eqerem Bey Vlora, p. 436). The leading role of Mehmet Konica is also proved by the letter of the delegates of Korce-Pogradec area addressed to the chairman of the national meeting, Mehmet Konica. The letter was written by Sotir Peci, Syrja Pojani and Idhomen Kosturi. After thanking him about the organization of the Congress, they expressed their grief that they could not participate in the congress because the city was occupied by French forces.

The meeting was opened with a short speech by Myfit Libohova because Mehmet Konica was absent in this session. M.Konica urged delegates the co-direction of the Assembly by Myfit Libohova and Fejzi Bey Alizoti. The Congress approved his proposal without objection, as it is reflected in the minutes administered by Lef Nosi, which affirm his representative authority, as the main organizer. According to the minutes of the congress, Myfit Libohova informed the congress that Mehmet Konica could not participate in the first session for "health reasons" (L. Nosi, Historical Documents, p. 290).

After the verification of mandates, a procedure that was conducted with the reading of the names, the delegate of Gjirokastra, atty. Vasil Dilo, proposed that the vice chairman of the Congress should be a Christian. Hiqmet Delvina proposed Petro Poga to be the vice chairman. Whereas Luigj Gurakuqi proposed that the representation was not done neither based on the provincial criteria "gegë or tosks", nor on the religious criteria. According to him the religion should be of free choice in a free country and urged delegates to elect a secretary and a deputy secretary. He proposed Mustafa Kruja and Sif Nosi, who were voted unanimously (L. Nosi, Dokumente Historike, p. 290).

The first institution established by the Assembly of Durres was its Chairmanship, with Mehmet Konica and Myfit Libohova, as co-chairmen. Petro Poga was the vice chairman, Mustafa Kruja was the secretary and Sif Nosi was the deputy secretary (L. Nosi, Historical Document, p. 270). With the election of the Chairmanship of the Congress, the congressional direction bodies were constituted. The procedure legitimized the decisions of the congress and the institutions that will be established by it. The agenda, by the formal procedure, adheres to the agreement that Mehmet Konica has made with Sonino for the establishment of only one Executor/Acting Committee and the approval of delegates who would participate in the Paris Peace Conference. Organizuesit e Kongresit kishin përgatitur në fshehtësi një skenar politik i cili u bë publik sapo mbaroi komunikimi i rendit të ditës, nga Myfit Libohova. Deputy Secretary of the Congress, Sif Nosi, demanded that a document prepared by the delegates should be introduced in the agenda for discussion. Namik Delvina and Riza Dani, on behalf of Qazim Bey Elbasani, Ismail Kadiu, M. Xhavit Metobashi, Muharrem Pelingii, Lef Nosi, Mustafa Hasim Kruja, Qerim Bej Begolli, (who was not a delegate), Ndoc Çoba, Ahmed Dakli, Sotir Peci, Ymer Deliallisi, Luigj Gurakuqi, Xhelal Belegu, Dr. Syrja Pojani, Abaz Kupi (who was not a delegate), Riza Dani, Rexhep Jella, Hasan Bey Zagolli, and Abdurrahman Bey Çela proposed that, instead of the Acting/Excecuting Committee, the Congress should establish an interim government (L. Nosi, Historical Documents, p. 288-289. The government established by the Congress was done on behalf of "National Meeting" and expressed the joy that the Albanian nation "by means of its 
representatives, showed publicly and manfully, the firm will to protect by all means the inalienable rights of Albania" (L. Nosi, Dokumente Historike, p. 290).

The only institution that was formed by legitimized delegates with "letter of representation" was the government of Turhan Pasha. ${ }^{7}$ The government was composed of Turhan Pasha, Chairman of the Government; Preng Bib-Dodë Pasha, Deputy Chairman of the Government; Mehdi Bey Frashëri, Interior Minister; Mehmet Konica, Minister of Foreign Affairs; Petro Poga, Minister of Justice; Luigj Gurakuqi, Minister of Education; Fejzi Alizoti, Minister of Finance; Sami Bey Vrioni, Minister of Agriculture; Mustafa Kruja, Minister of Post Telegraph; Lef Nosi, Minister of National Economy; Dr. Mihal Turtulli, Minister Without Portfolio; Myfit Bey Libohova, Minister Without Portfolio; Mit'hat Frashëri, Minister Without Portfolio (Sëire, Albania, the rise of a kingdom, 2007 p. 234).

In December 27, at 15.30 p.m, Mehmet Konica expressed the wish of the delegates that the Interim Government should be recognized by Italy, because even the Prime Minister, Turhan Pashë Përmeti, was known to be in favor of Italy. Mehmet Konica proposed the establishment of a Senate. On December 27, 1918, Mehmet Konica proposed that the eldership (assembly of older men) should be composed of two misësh of each county. The functioning of the eldership and its powers should be defined by nomi / Law. Eldership was due to meet once in two months in a place acceptable to examine the work done by the operating committee and to advise the committee (Marenglen Verli, Ferit Duka, Tirana, 2007, p. 291). In October 1919 was done the election of the members of the eldership and they arrived in Durres as well, but they have not been accepted by the government of Durres (M.Verli, Ferit Duka, Tirana, 2007, p. 298).

In this government, Mehmet Konica was elected foreign minister. Only after a month he could inform "Vatra" society in the US by telegram, through Yugoslavia, that congressional delegates had created a government that would represent Albania at the Peace Conference in Paris (J. Seir, p. 234). Political Representative of Italy at the National Council, Colonel Ettore Lodi, stated that delegates would not be allowed to leave from Durres, without revoking the Decision to establish a government. In these circumstances, Mehmet Konica went to Rome to explain the decisions taken by the Congress of Durres (Nikola Guy, 2012, p. 181).

\section{Government of Durres, Albania's legitimate representative at the Peace Conference in 1919}

Political and national inspiration arose when there was no sign of national rebirth. Albanian political elite faith was enhanced by the new configuration of political forces in Europe. In this situation, Interior Minister Mehdi Frashëri transmitted to Colonel Aubrey Herbert the belief that the Paris Peace Conference would be fair with the Albanian issue (Nikola Guy, p.181). Peace Conference did not recognize the Albanian delegation led by Turhan Pasha. In fact, the interim government of Durres was not known by any country of the Great Powers, because Italy did not allow any notice. Only a telegram of Mehmet Konica a month later to "Vatra", through Yugoslavia was published in the American press and sparked surprise (Joseph Seir, 2007, p.235).

Besides the official delegation mandated by the National Assembly of Durres, it was even the delegation of Esat Toptani. Esat Toptani, on October 6, 1918, gave an interview to "Journal de Genève" where he declared that "Europe knew his government" therefore he wouldl go to Paris as head of government of Albania. He diplomatically answered to the question made to him if he would become the Prince of Albania. The answer was: "I would decide it when the war is over". He called Austro-Hungary a hypocrite in the behavior with Vidi, and he stated that he was afraid of Italy. In that interview he tried to argue that he was a descendant of Prince Karl Topia and according to him "Albania should be a constitutional monarchy, like England" (Joseph Seir, Dituria, 2007, p.235). According to Edit Durham, the government "would have difficulties to represent itself in front of Esat Toptani, who was known by European diplomacy more than Ismail Qemali (Harris Silajxhiç, Dituria, 1999, p. 66). French newspapers "L'Excelsior", "L'Humanité" and "Le Petit Journal" described Toptani as head of Albanian government and chairman of the Albanian delegation (Arben Puto, 2009, p.225).

National movement has played a significant role with "national wing", which in November 1918 was renamed as "The Committee of National Defense of Kosovo", and was led by Hoxhë Kadri Prishtina, graduated in law, with Bedri Peja as a secretary and its newspaper" People "chaired by Sali Nivica. Istanbul's colony was represented by Fuat Dibra. Romania's colony was represented by Pandeli Evangjeli and Ibrahim Temo. National Party which was established in 1918 by Kristo Dako appointed Ismail Qemali, Parashqevi Qirjazi, Noureddin Vlora, Nikollë Ivanaj and Mihail Grameno (Haris Silajdzic, Albania and the United States ..., p. 36). 
With the arrival of Mehdi Libohovë and Myfit Frashëri in Paris, the proitalian lobby prevailed, but also pro-American factors were working intensively. Eriksson had sent a memorandum to President Wilson against Turhan Pasha "as a man sold to Italy and a man who did not represent Albania, whereas Esat Toptani considered him a man who did not represented anyone but himself" (Albanian People's History, Academy of Sciences. Vol. III, p. 137). Turhan Pasha and other members of the delegation, through the Italian delegate in Paris, A.De Martino, on May 28, 1919, stated that they knew "strategic interests" of Italy, and offers it, Sazan, Karaburun and Zverneci. The letter cast the idea of "an Italian prince on the throne of Albania (A.Puto, political Albania, the file no. 6 (26)). With this act, "the mandate" of Italy and the loss of the status acquired on July 29, 1913 were accepted. But the Treaty of July 29, 1919 Titton-Venizelos resulted in the boomerang effect for Italian influence in Albania, an event that marks the beginning of the Albanian uprising against the Italian presence in Vlora and beyond (Pastoreli, Pietro, pg.140).

Mehmet Konica and Dr. Mihail Turtulli established contacts with England, through Colonel Philips. Contacts were established with the captain Morton Eden, who was a consultant of the British delegation in Paris and a consul in southern Albania. Phillips became the spokesman of the Foreign Office. British delegate, Crowe sent a letter to the Foreign Minister, Lord Curzon, expressing the opinion that: "Albanians seem to have lost faith, that Italians are their defense and that by Titton-Venizelos agreement and the speech of Titton himself they have been convinced that Italians are a danger to Albanian independence, as much as Serbia and Greece" (Documents on British Foreign policy, 19191939. vol. IV.d.111). British Consul, Morton Eden, was very active. In December 1919 he went to Berat and Gjirokastra accompanied by Major Mustafa Maksuti and the former kadi Azis Tajari. In Gjirokastra he met the mayor Bega Beso and Javer Hurshit, and confidentially he said that the British government wishes the establishment of a National government, instead of the government of Durres as a tool of Italy. Furthermore, according to Sejfi Vllamasi, he ordered that if they were invited at the congress they would send Beso Bega and Veli Harshova as delegates (Marenglen Verli, 2000, p. 177). Eden's position is also confirmed by Eqerem Bey Vlora. According to him Morton Eden has hosted him at his home, but he did not believe that Congress could be organized, when Italians opposed it (Eqerem Bey Vlora, memories pg. 440). The Consul Eden stayed in Lushnjë the days of the congress, until its conclusion when he departed together with Phillips British Colonel (Joseph Seir, Dituria, 2007, p. 260).

\section{The circumstances that initiated the Congress of Lushnja as political and institutional monument}

In November 1919, the US consul in Torino, Josef Haven met Tefik Mborja, who was the Secretary General of the Government of Durres, and together they organized several meetings in Albania (Marenglen Verli, 2000, p.157). On December 29, 1919, Luigj Bumçi and Gjergj Fishta, met Pope Benedict the XV. Pope met ambassadors of England and US and urged the dismemberment of Albania. At these events the Americans and the British were very active in Albania and abroad, for the preparation of the Congress (N. Guy, p.180.). This fact allows us to reason that the British had begun to leave the "political apathy" for Albania. Consul Morton Eden, was a man of secret intelligence service. In December 1919 he went to Berat, Gjirokastra and Vlora. In Gjirokastra he met with the mayor Beso Bega and Javer Hurshitin. He confidentially told that the British government wishes the establishment of a national government, instead of the government of Durres (Marenglen Verli, 2000, p.177). Eden's position is also confirmed by Eqerem Bey Vlora, who in his memoirs admits that Eden "asked him to work for the congress, but I did not believe that its organization was possible and I went wrong" (Eqerem Bej Vlora, Memories pg 440).

The Congress of Lushnja initiator was the organization called "National Wing" which in November 1918 was renamed, becoming "National Defense Committee of Kosovo". On December 4, 1918, "Kosovo Committee" asked President Wilson, in the name of humanity and honor, to send a unit of international forces against Montenegrin forces in Plave and Gusinje. ${ }^{8}$ At the end of November 1919 in the house of Abdul Ypi, the national wing group, with Sotir Peci, Esheref Frashëri, Fazlli Frashëri, Sali Vuciterni, Halim Gostivari, Xhevit Leskoviku and Seji Vllamasi, discussed on the anticipation of the congress. There was decided that Fazlli Frashëri should go to Korçë, Sejfi to Shkodër and Zogu to Mat. ${ }^{9}$ From 1917 Zogu also joined "national wing". On August 18, 1919, Ahmet Zogu proposed to the Municipal Council of Elbasan to take the initiative, being the city in the center of Albania, to organize a national meeting (Kastriot Dervishi, $p$. 98). The following personalities have given their contribution: Aqif Pashë Elbasani, Abdi Toptani and Ismail Ndroqi,

${ }^{8}$ Historical documents and materials from the Albanian people's struggle for freedom and democracy, 1917-1941, published in 1959 Aqsh p.8, H.Silajxhiç, Albania and the United States ..., p.99. File V.Uilson Letter of "Kosovo Protection Committee", 10/12/1918

9lbid, p.165 
chairman of the villagers of Tirana, Osman Myderrizi, chairman of "Drita" Society in Tirana and Mytesim Këllici. Abdi Toptani was an old, discreet, honest patriot and credible to the circle of nationalists in Tirana and Kruje. The relation of Aqif Pasha with Abdi Toptani was assessed to be crucial for the authority they had in political circles. Their relationship has become possible by Hafiz Ali Korca (Hafiz Ali Korca 2006 p.5). Hafiz Ali Korca, in his book titled "Seven dreams of Albania", written in 1924, assesses Ferid Vokopola as one of the most ardent initiators. Ali Korça himself has brokered the merger of two personalities Aqif Pasha and Abdi Toptani, with great influence and significant importance for organizing the convention.

Sheh Ibrahim Karbunara and lliaz Vrioni have had an impact in Berat. Captain Meleq Frashëri went to Berat and secured the consent and support of Iljaz Vrioni on the meeting of Congress in Lushnjë. Only when lliaz Vrioni expressed his support for the Congress, the organizing committee sent notices to every municipality (Marenglen Verli, 2000, p. 190). The ministers of the government of Durres such as Mehmet Konica, Mihal Turtulli and Lord Luigj Bumçi played a special role, who welcomed the organization of the congress. The congress was also attended by people of Esat Pasha, Osman Bali, Osman Mema, Hamit Toptani etc., thinking that after the congress, Esat, with his authority, could take charge of the country. Congress seriousness is also demonstrated by commission with 22 members: with Ferid Vokopola, Xhavit Leskoviku, Eshref Frashëri, Xhemal Bey Prishtina, Halit Libohova, Llazar Bozo, Besim Nuri, Hysni Curri, Mustafa Vokopola, Emin Vokopola, Abedin Ibrahimi, Qemal Mullai, Syrja Pojani, Nebi Sefa, Rasim Hoxha, Abedin Nepravishta, Abdulla Aga, Arif Qafmolla, Jakov Bozo, Hasan Abedini, Taulla Sinani, Reshit Shazimiri and Hamit Xheka (AQSH, War of the Albanian people, 1976 p.13)

Italy, pro Italian feudal lords such as Shefqet Verlaci and pro Italian ministers such as Mufid Libohova, Fejzi Alizoti and Mustafa Kruja were against the Congress (Sefji Vllamasi, pg. 193). On January 13, 1920, Fejzi Alizoti, with the mandate of the interior minister, commanded the deputy prefect of Lushnja, Veli Vasjari, to stop the congress, as it had a political character (Documents and historical materials 1917- 41, 1959 pg. 16).

\section{Conclusions}

- Completion of the First World War quashed the political balances between Italy and the Austro-Hungary and enabled Italian diplomacy to enhance its influence on Albanian political elite.

- Foreign Minister, Baron Sonino authorized the Director of the Albanian office in Rome, Colonel Vincent, to contact Mehmet Konica and Myfit Libohova to go to Albania with the aim to establish an "Committee Execution" but not a national government.

- I think the role of Mehmet Konica for organizing the National Assembly of Durres has been crucial and therefore his activity requires a reassessment. He was known for his diplomatic skills, but in December 1918 he showed great political and organizational skills. Mehmet Konica, within a month, could organize a National Assembly with delegates who had the mandate to establish a National Council. Mehmet Konica, through several procedures, authorized Namik Delvina and Riza Dani, who through a procedure in the Assembly, on behalf of a large group of delegates, enabled the creation of an interim government.

- By decision of the National Assembly, a delegation with the ministers of the government was established, which would represent Albania at the Peace Conference in Paris, destroying the plans of Italy.

- Organization of the Congress of Lushnja is a merit of Albanian political elite, who for the first time established all political institutions of the Albanian state without the influence of the international community, showing selfgoverning skills.

- One of the shortcomings of the Albanian political elite for the Congress of Durres and the Congress of Lushnja was the establishment of political institutions, without constitutional legal norms.

- In the 1920s, parliamentary life was established as an institutional political innovation with Western orientation, but Albanian politicians could not determine the shape of the state governance through a constitutional assembly by elections.

\section{Reference}

Marenglen Verli, Tiranë: Neriada, 2000, p.150

Syrja Vlora, Memories, Tirana: Iceberg 2012, p.168

Arben Puto, Political Albania...., p. 222

Documents and historical materials from the Albanian people's struggle for freedom and independence, 1917-1941, edition of Aqsh Tirana, 1959, p.17, p.21, p.22 
Aqsh, F.55, d.62.f.3, circulars of Min. of Interior Affairs of 1920 Shkoder: Nika, 1921, p. 3.

AQSH.F.249.D.I-1842.f.1-2.poza 4.

Lef Nosi, Historical Documents 1912-1918, prepared by Marenglen Verli, Ferit Duka, Tirana, Mother Teresa, 2007, p. 291, p. 298, p. 300-301, Aqif Pasha letter for the Chairman of Albanian Meeting, Durres, dated December 20, 1918.

Aqsh, F.55, D.46, fl.1; Letter of S. Peci, Syrja Pojani and Idhomen Kosturi; L.Nosi, Historical Document, p. 290.

L. Nosi, Historical Documents, p. 290, p. 288-289.

Haris Silajdzic, Albania and the United States ... Constitutive Act of the Provisional Government of Durres, dated 25 .1.1919; General archives of the American Committee for the negotiation of peace, 1918-1931, Albania, 875.00.2 (M820r.555).

Joseph Seir, Albania, the rise of a kingdom, Tirana: Dituria 2007 f. 234, p. 235, p. 260

Teki Selenica, Albania in $1927 . . .$, p.16

Kruje, P.P.Margjikaj, Correspondence 1947-1958, Shkodër, 2006, p. 136-137.

Nikola Guy, The Birth of Albania, Tirana, Pegi, 2012 f.181. Referring DDI, Series 6, I, no. 660.661, 694.732.

Haris Silajdzic, Albania and USA in Washington's archives, Tirana: Knowledge, 1999, p. 36, p. 66

Arben Puto 1912-1939 Political Albania, Tirana: Toena, 2009, p. 225

History of Albanian People, a publication of the Academy of Sciences. V. III, p. 137.

A.Puto, political Albania, the the Fundof foreign ministry, file No. 6 (26).

Pastoreli, Piettro, Esera policy L'italiana nella Albania 1914-1920, Napoli, Joven, quoted by A.Puto 1970.L'Albania.p.140, Albania

Documents on British Foreign policy,1919-1939.1 series vol.IV.d.111

Sejfi Vllamasi, Political confrontation in Albania, 1897-1942, Marenglen Verli, Tirana: Neriada, 2000, p. 177

Eqerem Bey Vlora, Memories p.440

Sejfi Vllamasi, Political confrontation in Albania, 1897-1942, Marenglen Verli, Tirana: Neriada, 2000, p. 157, p. 177

N. Guy, The Birth of Albania..., f.180.

Historical documents and materials by the Albanian people's struggle for freedom and democracy, 1917-1941, published in 1959 Aqsh p.8, H.Silajxhiç, Albania and the United States ..., p.99. File V.Uilson Letter of "Kosovo Protection Committee", 10/12/1918.

Kastriot Dervishi, the Albanian State History ... 1912-2005, p. 98.

Hafiz Ali Korca, Seven dreams of Albania, Tirana, 2006 p.5

Sejfi Vllamasi, Political confrontation in Albania 1897-1942, prepared for publication by Marenglen Verli, Tirana: Neraida, 2000, p. 151152, pp. 190.

Aqsh War of the Albanian people for national liberation, 1918-1920 Tirana 1976 p.13

S. Vllamasi, Political confrontation ..., p. 193.

Documents and historical materials from the Albanian people's struggle for freedom and independence 1917-1941, Tirana, 1959, p.16 
